\title{
CATEGORIES OF DEFINITENESS IN CLASSICAL ARMENIAN
}

\author{
ANGELIKA MÜTH \\ University of Oslo
}

\section{[1] THE DEVELOPMENT OF DEFINITENESS MARKERS}

The development of definite articles from demonstrative pronouns is a phenomenon often quoted as a standard example for the process of grammaticalization (cf. e.g. Lyons 1999, 331-334). In many of the modern European languages that have an article-like marker of definiteness this definite article goes back to a further demonstrative, e.g. French le, Italian il, Spanish $e l<$ Vulgar Latin ille, English the < OE poet 'that one', ${ }^{1}$ German der, die, das < OHG dër, diu, daz 'that one' (sometimes used as definite article already in OHG times). This development can in many cases be described as a combination of two functional processes (Manolessou \& Horrocks 2007, 224ff.). First a (usually distal) demonstrative pronoun employed attributively as NP determiner gradually looses its demonstrative sense keeping only the definite semantic content. Often this development will take its starting-point either in certain "key environments" or with somehow specified NPs (e.g. re-topicalized agents within narrative contexts, or NPs with superlative, ordinal or contrastive arguments, etc.). In a second step, the grammaticalized article spreads its usage from "established" contexts into new employments where it is first optional (motivated by specific contextual requirements) and later becomes an obligatory grammatical marker.

\section{[1.1] Greek}

As recently discussed by Manolessou \& Horrocks (2007), the case of Greek provides an especially illuminating example of this development. Even though both of the above mentioned processes-(i) gradual loss of demonstrative meaning in certain environments and (ii) spread of the article usage into other contexts-belong to the 'Dark Ages' within the history of Greek, it is possible to trace the development in its general lines (see Table 1 on page 12).

Mycenean Greek, the oldest attested stage of the language, does not show any evidence for a definite article. The forms ho, hê, tó < PIE *so, ${ }^{*} \mathrm{seh}_{2}$, ${ }^{\text {to- }}$ have merely the function of an anaphoric pronoun meaning 'that one'. In the Homeric poems

[1] The etymological original of the is $\mathrm{OE} s \bar{e}$ (masc.). The initial $s$-is replaced by $p$ - analogically to the neuter form poet which is from the 13th century on the only form. Later the inflection disappears and the definite article develops. The actual demonstrative poet is continued in Modern English that. 


\begin{tabular}{lll}
\hline $\begin{array}{l}\text { Mycenean } \\
\text { Homeric Greek }\end{array}$ & $\begin{array}{l}\text { 14.-16. century BC } \\
\text { ca. } 800 \mathrm{BC}\end{array}$ & $\begin{array}{l}\text { no definite article } \\
\text { demonstrative ho, hê, tó mainly } \\
\text { used as anaphoric pronoun; } \\
\text { already article-like use in } \\
\text { NPs determined by ordinals, } \\
\text { superlatives, contrastive at- } \\
\text { tributes } \\
\text { "fully developed" article, used } \\
\text { to convey pragmatic definite- } \\
\text { ness } \\
\text { an article (definite or indefinite) } \\
\text { is obligatory in almost all argu- } \\
\text { ment NPs }\end{array}$ \\
\hline
\end{tabular}

TABLE 1: The article in the history of Greek

(written down first around $800 \mathrm{BC}$ after a long prehistory of oral tradition), the same pronoun is still used mainly anaphorically, but can also occur as a noun determiner having mainly the function of re-topicalizing a previously mentioned noun. When occuring in NPs with ordinal, superlative or contrastive head nouns, however, one can already find an article-like usage in the sense of the later marker of definiteness (cf. the Homeric examples in Manolessou \& Horrocks 2007, 228f.). In Classical Greek we find a "fully developed" article mainly used to convey pragmatic definiteness (cf. section [2] below). In contemporary spoken Modern Greek, the use of articles (either definite or indefinite) is obligatory in almost all argument NPs (with the exception of predicatives).

\section{[1.2] Armenian}

The situation in Classical Armenian, as described by Klein (1996), is quite different, regarding both formal and functional aspects. In general, one has to do with a triple system of proximal, medial and distal deixis/definiteness which we find among other IE languages most similarly in Latin (hic, iste, ille). The core elements, Arm. $-s$ - (proximal), $-d-$ (medial), $-n-$ (distal) occur as enclitics $-s,-d,-n$ affixed to nouns and are in Classical Armenian considered to be definite articles denoting a certain personal affinity: -s refers to the first person/the speaker, $-d$ to the second person/the addressee, while the by far most frequent $-n$ seems to be a rather neutral, "simply definite" article. The very same triple distribution is found in the Armenian system of anaphorics ( $\mathrm{sa} / \mathrm{da} / \mathrm{na}$ 'this one [here]/that one [by you]/that one [over there]'), demonstratives (ays/ayd/ayn), identity pronouns (soyn/doyn/noyn), as well as in several adverbs (e.g. ayspês/aydpês/aynpês 'this/that there/that way', etc.). Be- 
cause these three elements occur in a range of pronominal stems as well, one may ask whether the clitics $-s,-d$, $-n$ were the original base for a further evolution of the several demonstrative stems or if the development was rather the other way around, i.e. that the demonstrative series $s a / d a / n a$, ays/ayd/ayn, soyn/doyn/noyn existed primarily and the clitic articles $-s /-d /-n$ were later 'abstracted' from these forms. I will not go into further detail about this question here, but arguments may be found for both directions of development. The "condensation" from original demonstrative stems to single clitic elements $-s-/-d-/-n$ - is corroborated by the fact that corresponding demonstrative stems exist in related IE languages as well (cf. Skt. $s a$, Lat. is-te, OCS onŭ, etc.). A secondary abstraction of the Armenian clitics -s/-d/ -n might have been effected by contact with surrounding Caucasian languages which have partially similar triple systems of nominal deixis. For example, Udi, the modern descendant of Caucasian Albanian, a language which was certainly in contact with Classical Armenian, has three deictic elements, - $m$ - (proximal) / - $k a-$ (medial) / -t'e- (-s(e)-) (distal), which are functionally similar to the Armenian clitic articles, cf. Schulze (2008).

The principle of article affixation seems in general to be to a certain degree sensitive to language contact. Among IE languages, affixed articles often occur within coherent geographic areas such as the Scandinavian language area or the Balkan Sprachbund (Romanian, Albanian) (Dryer 2005). The same holds true for Armenian which genetically belongs to the IE language family but at the same time contains many traits presumably influenced by the surrounding Caucasian language area (e.g. the lack of grammatical gender).

In this paper I will approach the question of which semantic and pragmatic types of nominal definiteness we find in the language stage of Classical Armenian as attested in the 5th century translation of the New Testament. Before I discuss the Armenian data I will present some elementary categories of semantic and pragmatic definiteness as differentiated in standard approaches (section [2]), and briefly address the concept of a "development path" of definiteness along stages as proposed by Greenberg (1978) (section [3]). In section [4], I show how this category system works for the language of the Classical Armenian Bible translation compared to the Greek text. In the conclusion I return to the question of whether Armenian provides any additional evidence for Greenberg's concept of the unidirectional development of definite articles.

\section{[2] CATEGORIES OF DEFINITENESS}

Löbner's (1985) categorization system of nominal definiteness is based on the distinction between the functional, relational and sortal concepts. Sortal nouns simply classify objects (e.g. girl), while relational nouns have arguments (e.g. a daughter must be the daughter of someone). Functional nouns are relational nouns that identify the referent unambigously (e.g. 'mother (of X)' cannot refer to more than 
Lexically inherent definiteness

Generic reference nouns proper nouns, 1st/2nd person pronouns, unique reference nouns (e.g. the sun, the Prime minister)

e.g. The dog is man's best friend.; in abstract situations without any real-world referent: sie geht in die Kirche but She goes to church

NPs with superlative, ordinal or polar contrastive arguments the tallest boy (i.e. of the set of $x$ boys)

the third occasion (i.e. of the set of $n$ occasions)

the other book (i.e. of the set of two books)

TABLE 2: Semantic definiteness

one individual).

Another basic assumption is the distinction between semantic and pragmatic definiteness. Semantic definites refer to functional concepts independently of the situation, while the reference of pragmatic definites crucially depends on the particular situation they are embedded in.

I will start by discussing semantic definiteness (see Table 2). Proper names, 1st/2nd person pronouns and unique reference nouns (e.g. the sun, God, the Prime Minister) denote functional concepts which are inherently definite by virtue of their lexical meaning alone. The uniqueness of a noun, however, can be limited to the scope of a specific universe which it is uttered in, e.g. the Prime minister can basically refer to a range of individual Prime ministers, but would still have a unambiguous referent within the certain universal context it is used in.

Common nouns that are otherwise non-functional are regarded to be semantically definite when used generically (i.e. when referring to a whole class/genre, e.g. The dog is man's best friend.) Here, languages typically differ with respect to the use of the definite article (cf. the discussion on page 19 below).

Another kind of semantic definiteness arises when a noun is determined by superlative, ordinal or polar contrastive attributes (e.g. the tallest man, i.e. of the set of men, the third occasion, i.e. of the set of occasions, the other book, i.e. of the set of two books).

Pragmatic definites, by contrast, acquire unambigous reference within the particular linguistic (or extralinguistic) context in which they are used. There are different kinds of pragmatic definiteness. Definites may be used to express anaphoricity, as in (1): 
(1) a. A key was stolen from the office. Two days later the key was used to obtain entry to the building.

b. A girl entered the room. The girl was about seven years old.

Definites may also be cataphoric (or endophoric), e.g. when used with specifying relative clauses or attributes:

(2) the prize that she won last year

Finally, definites may have a deictic function in cases where the definite description refers directly to constituent features of the extralinguistic situation:

(3) Mind the gap!

Since the use of the definite article with pragmatic definites is thus 'motivated' by certain features of the context, it is to be expected that a language will first develop and then quickly generalize the article in precisely those environments where it is functional. Consequently, if the usage of the definite article with pragmatic definites is still optional in a given language, its main function may still be a semantic one.

\section{[3] “STAGES” WITHIN THE SPREAD OF THE DEFINITE ARTICLE}

As proposed by Greenberg (1978) and adapted to the example of Greek by Manolessou \& Horrocks (2007), there seems to exist a regular "path" of development from the emergence of definite articles onto a further expansion/gradual spread of usage:

(4) Stage 0: no definite article (other means are employed to convey the notion of definiteness);

Stage 1: the article emerges from a (usually distal) demonstrative;

Stage 2: the article becomes more generalised, e.g. into non-definite, but specific uses, with resistence from proper names, generics, predicate nominals, incorporated objects etc.;

Stage 3: the "article" loses all inherent semantic content, becoming simply a marker of e.g. class (gender), number, or mere nominality.

This path of development is supposed to be unidirectional and to reflect both the synchronic variation between different languages and the diachronical variation between several stages of development within a given language. That is, there will e.g. not be a use of the definite article with proper names unless the definite article is at the same time also used with common nouns, or it will not be used on possessives unless it is also a used with generic reference nouns. Any extension of article usage over time will take place in categories other than "simple definite". 


\begin{tabular}{lllll}
\hline & & Definite & Bare & Total (Gosp.) \\
\hline Jesus & Greek Iêsous & 431 & 357 & $788(\mathrm{NT})$ \\
& Cl.Arm. Yisows $\left({ }^{*} Y S^{*},{ }^{*} \mathrm{YI}^{*},{ }^{*} \mathrm{YE}^{*},{ }^{*} Y I W^{*}\right)$ & 1 & 552 & 553 \\
\multirow{2}{*}{ Pilate } & Greek (Pontios) Peilatos & 43 & 8 & 51 \\
& Cl.Arm. (Ponce) Piłatos & 0 & 50 & 50 \\
\hline
\end{tabular}

TABLE 3: Jesus and Pilate

\section{[4] TYPES OF DEFINITENESS IN GREEK AND ARMENIAN}

In the following I will give a quantitative overview of how Greek and Classical Armenian make use of the definite article within the functional categories of definiteness presented in section [2].

\section{[4.1] Semantic definiteness in Armenian}

\section{Proper nouns}

Among the unambiguous ${ }^{2}$ proper names found in the NT, Jesus and Pilate may serve as good examples (see Table 3).

Greek and Armenian follow different rules in the use of the definite article. Even though proper names generally contain an "inherent definiteness", instances with the definite article in the Greek version clearly predominate compared to instances without the article. The Armenian translation, on the other hand, seems to avoid any kind of article on proper names. ${ }^{3}$

However, there seem to be exceptions with proper names for especially sacred (or respected) persons, such as the prophets Eliah and Moses who are in many cases mentioned in one and the same sentence (e.g. Mt 17:3 kai idou ôphthê autois Môusês kai Hêleias sunlalountes met' autou).

Eliah never appears with the definite article, neither in the Greek nor in the Armenian version. The instances of Moses are all bare in the Armenian text and overwhelmingly bare in the Greek one. The five Greek instances of Moses with the definite article (Mt 23:2, Jn 7:22 [twice], Jn 7:23, Jn 9:28) are clearly influenced by other (rather pragmatic) factors. Consider, e.g., the re-topicalization in example (5): Moses is first introduced in the context as a bare noun and then referred back

[2] One has to pay attention to the fact that many proper names occuring in the NT can refer to at least two individuals within the biblical universe (e.g. John $=1$. John the Baptist, 2. the son of Zebedee, 3. the father of Peter; Herod =1. Herod the Great, 2. the tetrarch introduced e.g. at the beginning of Mt 14; Joseph =1. the husband of Mary, the mother of Jesus, 2. the brother of Jesus, 3. a rich man of Arimathaea (Mt 27:57-61), besides, there are at least two other persons named Joseph mentioned in the Acts).

[3] The only instance of *YS* with article $-n$ is clearly motivated by its position within a relative clause. Cf. Jn 9:11: Na et patasxani' ayr mi orowm * $Y S^{*}-n$ asen 'kaw arar cep 'eac' $z$-ačs im 'ew asê c 'is ert' $i$ Siłovam ew lowa č ogay lowac'ay. ew tesaném : "He replied, "The man they call Jesus made some mud and put it on my eyes. He told me 'Go to Siloam and wash.' I went, I washed, and I see."'. 


\begin{tabular}{lllll}
\hline & & Definite & Bare & Total (Gospels) \\
\hline \multirow{2}{*}{ Eliah } & Greek Hêleias & 0 & 27 & 27 \\
& Cl.Arm. Ëłia & 0 & 27 & 27 \\
Moses & Greek Môusês & 5 & 30 & 35 \\
& Cl.Arm. Movsês & 0 & 35 & 35 \\
\hline
\end{tabular}

TABLE 4: Eliah and Moses

\begin{tabular}{lllll}
\hline & & Definite & Bare & Total (Gosp.) \\
\hline \multirow{2}{*}{ Jerusalem } & Greek Hierousalêm, Hierosolyma & 4 & 62 & 66 \\
& Cl.Arm. Erowsatèm $\left({ }^{*} E M^{*},{ }^{*} \bar{E} M^{*},{ }^{*} E \bar{E} M^{*}\right)$ & 0 & 65 & 65 \\
\multirow{2}{*}{ Gordan } & Greek Iordanês & 15 & 0 & 15 \\
& Cl.Arm. Yordanan & 0 & 15 & 15 \\
\hline
\end{tabular}

TABLE 5: Jerusalem and Jordan

to with the (anaphoric) article in the following verses:

(5) ou Môusês dedôken humin ton nomon? [...] ho Môusês dedôken humin tên peritomên (oukh hoti ek tou Môuseôs estin all' ek tôn paterôn)

'Did not Moses give you the law? [...] Moses therefore gave unto you circumcision (not because it is of Moses, but of the fathers).' (Jn 7:19-22)

Regarding place names, Jerusalem and Jordan provide representative examples, as shown in Table 5. The city of Jerusalem is referred to by two variants of the name, the sacral name Hierusalém used by Jewish authors (showing up mainly in the Acts) and the profane name Hierosólyma addressed to non-Jewish readers (Blass \& Debrunner 1979, 45).

Among the total 66 instances of Jerusalem in the Greek text, only four are definites while the same name never has an article in the Armenian translation. The four Greek instances with article are all forms of Hierosoluma and all of them occur in John (Jn 2:23, 5:2, 10:22, 11:18). In contrast stands the example of the river Jordan which is always definite in Greek and never definite in the Armenian text.

It thus seems that Armenian avoids the definite article with proper nouns (which are definite qua their lexical meaning) while Greek seems to already employ the definite article in a rather pragmatic way (e.g. in order to re-topicalize a referent introduced earlier, etc.). 


\begin{tabular}{lllll}
\hline & & Definite & Bare & Total (Gospels) \\
\hline 'God' (sg.) & Greek theos & 688 & 209 & $897(\mathrm{NT})$ \\
& Cl.Arm. Astowac & $5(7)$ & $311(309)$ & 316 \\
'sun' & Greek hêlios & 10 & 2 & 12 \\
& Cl.Arm. aregakn & $0(1)$ & $9(8)$ & 9 \\
'death' & Greek thanatos & 2 & 26 & 28 \\
& Cl.Arm. mah & $1(2)$ & $28(27)$ & 29 \\
'gospel' & Greek euaggelion & 12 & 0 & 12 \\
& Cl.Arm. awetaran & $10(9)$ & $9(10)$ & 19 \\
\hline
\end{tabular}

TABLE 6: Unique reference nouns

\section{Unique reference nouns}

Among common nouns having a unique reference within the biblical universe, the notions of 'God' (sg.), 'sun', 'death' and 'gospel' can be taken as representative examples. The numbers are given in Table 6.

The Armenian Astowac 'God' seems to be treated in the same way as a proper noun avoiding the definite article.

In the case of Cl.Arm. aregakn 'sun' there is only one instance with the definite article $-n$ (only manuscript $\mathrm{E}$, missing in $\mathrm{M}$ ). Here the article obviously refers to the whole idiomatic infinitive construction ïmtanel aregakan- $n$ 'in the setting of sun':

(6) Opsias de genomenês hote edu ho hêlios...

ew ibrew erekoy ełew ï mtanel aregakan-n (M: aregakan)...

'And at even, when the sun did set...' (Mk 1:32)

A very similar distribution appears for the unique reference noun 'death'. The only example for definiteness both in Greek and Armenian is Jn 11:13 where the definite article may be motivated by the following possessive pronoun, referring to Lazarus (Gk gen.sg. autou = Cl.Arm. nora):

(7) eirêkei de ho Iêsous peri tou thanatou autou

Aył *YS* vasn mahow-n nora asêr

'Howbeit Jesus spake of his death.' (Jn 11:13)

The 12 instances of Greek euaggelion in the Gospels are all definite. The Armenian equivalent awetaran occurs 20x in the Gospels. This number includes, however, the 8 bare opening/closing phrases awetaran ast Mat'eosi, etc., at the beginning/end of each Gospel which are lacking in the Greek text. Among the 12 remaining instances there are 2(1) bare instances corresponding to definites in Greek. One of these, shown in (8), is found in a manuscript variant, the second, shown in (9), is part of a 
genitival syntagm, where the absence of the article is unexpected.

(8) êlthen ho Iêsous eis tên Galilaian, kêrussôn to euaggelion tou theou ékn *YS* ï Gałiłea : K'arozêr z-awetaran-n (M: z-awetaran) *AY* 'Jesus came into Galilee, preaching the gospel of the kingdom of God.' (Mk $1: 14)$

(9) Arkhê tou euaggeliou Iêsou Khristou Skizbn awetarani ${ }^{*} \mathrm{YS}^{*}{ }^{*} \mathrm{~K}^{\mathrm{I}} \mathrm{I}^{*}$

'The beginning of the gospel of Jesus Christ, the Son of God' (Mk 1:1)

\section{Generic reference nouns}

Generic reference nouns do not refer to individuals but to generic classes or kinds. In principle all common nouns can have a generic reading (with a certain emphasis on animate nouns such as anthrôpos, etc.), and therefore a quantitative approach is not appropriate. In order to get a first approximate picture we can have a look at some random examples of NPs with generic reference:

(10) hêpsukhê pleion estin tês trophês... zi ogi arawél è k'an z-kerakowr...

'The life is more than meat...' (Lk 12:23)

(11) gegraptai, ouk ep' artô monô zêsetai ho anthrôpos...

greal ê · t'e oč hac'iw miayn kec'c'ê mard...

'It is written, Man shall not live by bread alone...' (Mt 4:4)

In both examples the generic reference of the NP is indicated by the definite article in Greek (hêpsukhê/ho anthrôpos) while the Armenian counterparts (ogi/mard) occur as bare nouns. In fact languages often behave differently in whether and how they express kind reference. Often one and the same language has more than one way of expressing such a generic reference, e.g. English and German (see Table 7) ${ }^{4}$ (with differences in the degree of acceptance/frequency).

Classical Armenian apparently does not use the definite article for denoting generic reference. The same seems to be true for reference to ethnic groups (such as 'the Jews' in (12)) or categorical groups (such as 'the dead' in (13)).

(12) hoti hê sôtêria ek tôn Ioudaiôn estin zi p'rkowt'iwn ï hrêic' ê

'for salvation is from the Jews.' (Jn 4:22)

[4] In English, The man is only acceptable in cases where the NP is textually anaphoric, hence definite, not generic. 


\begin{tabular}{ll}
\hline English & German \\
\hline Man does not live on bread alone. & *Mensch lebt nicht vom Brot allein. \\
${ }^{*}$ The man does not live on bread alone. & Der Mensch lebt nicht vom Brot allein. \\
A man does not live on bread alone. & Ein Mensch lebt nicht vom Brot allein. \\
Men do not live on bread alone. & Menschen leben nicht vom Brot allein. \\
The men do not live on bread alone. & Die Menschen leben nicht vom Brot allein \\
\hline
\end{tabular}

TABLE 7: Generic reference

(13) hôsper gar ho patêr egeirei tous nekrous...

Zi orpês hayr yarowc'anê z-mereals...

'For just as the Father raises the dead...' (Jn 5:21)

Nouns determined by superlative, comparative or ordinal attributes

Nouns determined by superlative attributes have definite articles in Greek. The corresponding Armenian "absolute superlatives", ${ }^{5}$ in contrast, usually lack the definite article, cf. examples (14) and (15):

(14) ti emoi kai soi, Iêsou huie tou theou tou hupsistou;

zi? Kay im ew k'o *YS* ordi *AY* barjeloy

'What have I to do with thee, Jesus, thou Son of the most high God?' (Mk 5:7)

(15) eph' hoson epoiêsate heni toutôn tôn adelphôn mou tôn elakhistôn, emoi epoiêsate

orovhetew ararêk' miowm y-ełbarc's aysoc'ik p'ok'rkanc'. inj ararêk'

'Inasmuch as ye have done it unto one of the least of these my brethren, ye have done it unto me.' (Mt 25:40)

The same goes for NPs determined by ordinal attributes such as 'the first, the second, the third', shown in examples (16) and (17). Greek here always uses the definite article while the Armenian version translates without the article:

(16) kan en tê deutera, kan en tê tritê phulakê elthê... ew et' $y$-erkrord . kam y-errord pahow ekec'ē...

'And if he shall come in the second watch, or come in the third watch...' (Lk $12: 38)$

(17) kai tê hêmera tê tritê anastêsetai.

ew y-erir awowr yaric'é

'and the third day he shall rise again.' (Lk 18:33)

[5] Lacking a morphological comparison system, Armenian renders Greek superlatives by lexical adjectives with superlatival meaning. 
Interestingly, if the attribute occurs as a nominalized head noun, Armenian employs the article in order to specify/define the referent:

(18) ho de meizôn humôn estai humôn diakonos.

Ew mec-n $n$ ijênj elic i i jer spawór

'But he that is greatest among you shall be your servant.' (Mt 23:11)

The same holds for nominalized comparatives:

(19) all' ho meizôn en humin ginesthô hôs ho neôteros

aył or mec-n ēii jez. elic'i ibrew z-krtsér-n

'...but he that is greatest among you, let him be as the younger.' (Lk 22:26)

Nouns determined by polar contrastive attributes

Regarding the use of the definite article in NPs consisting of a contrastive attribute such as 'the other', Greek and Armenian behave exactly the same way. In these cases, the definite article is obligatory:

(20) ho de Petros eistêkei pros tê thura exô. exêlthen oun ho mathêtês ho allos ho gnôstos tou arkhiereôs...

Ew Petros kayr ar dran-n artak' oy :. El miws ašakert-n or êr canawt 'k'ahanayapeti-n...

'But Peter stood at the door without. Then went out that other disciple, which was known unto the high priest...' (Jn 18:16)

(21) ên de ekei Mariam hê Magdalênê kai hêallê Maria

And êr Mariam Makdałenac' $i \cdot$ ew miws Mariam-n

'And there was Mary Magdalene, and the other Mary.' (Mt 27:61)

\section{[4.2] Pragmatic definiteness in Armenian}

When it comes to defining the use of the definite article within textual-pragmatic relations such as anaphoric or cataphoric definiteness, the situation is less clear. In anaphoric expressions the use of the article is compulsory in both Greek and Armenian. Regarding cataphoric deixis, however, the two seem to go separate ways with Greek sometimes having the article and sometimes omitting it, while the Armenian equivalent always exhibits it.

\section{Anaphoric definiteness}

(22) kai epedothê autô biblion tou prophêtou Hêsaïou, kai anaptuxas to biblion heuren topon hou ên gegrammenon.

Ew etown nma girs z-Ësayay margarēi. ew yareaw ənt'ē̄nówl; ew ibrew ebac' $z$-girs- $n$. egit z-áyn tełi y-orowm greal-n ēr; 
'And they gave him the book of the prophet Isaiah. And he arose to read. And when he opened the book, he found the place where it was written,' (Lk 4:17)

(23) kai autos ên hestôs para tên limnên Gennêsaret, kai iden duo ploiaria hestôta para tên limnên

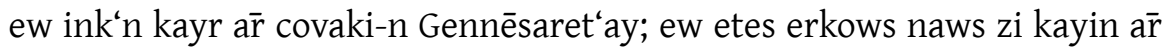
covaki-n

'He stood by the lake of Gennesaret and saw two ships standing by the lake.' (Lk 5:1-2)

\section{Cataphoric (endophoric) definiteness}

A special-and much more frequent-sub-category of cataphoric deixis is the socalled endophoric deixis: A new, previously unmentioned item is determined by a following attribute, often a restrictive relative clause. The following examples require some brief annotations.

(24) kai egeneto hôs êggisen eis Bêthphagê kai Bêthanian pros to oros to kaloumenon elaiôn...

Ew ełew ibrew merjec'aw ï Bēt'p‘agē ew ï Bēt'ania mawt $\ddot{i}$ learnn-n or kočc $i$ jit'eneac'...

'And it came to pass, when he was come nigh to Bethphage and Bethany, at the mount called the mount of Olives...' (Lk 19:29)

In (24), Greek and Armenian both make use of the definite article in an NP which is immediately followed by a determining attribute. The attribute is, however, not of the same kind. Greek has a participle (kaloumenon) while Armenian-which usually translates Greek participles by finite constructions-makes use of a subordinate relative clause (or koč $i$ ).

(25) kai mnêsthênai diathêkês hagias autou, horkon hon ômosen pros Abraam ton patera hêmôn...

ew yišel z-owxt-n iwr sowrb; z-erdowmn-n (M: z-erdowmn) z-or erdowaw Abrahamow hawr merowm

'and to remember his holy covenant; The oath which he sware to our father Abraham...' (Lk 1:72-73)

In example (25), Armenian and Greek differ from each other, although the syntax is identical. Both versions exhibit a subordinate relative clause as the determining attribute of the NP 'the oath'. The Armenian NP, however, is accompanied by a definite article (z-erdowmn- $n$ ) while the Greek one lacks it (horkon). Note that the Armenian manuscript $\mathrm{M}$ does not have the article (z-erdowmn). The genuine Armenian expression, however, is probably that with the article (as in manuscript E), because 
it is the lectio difficilior in that it differs from the Greek archetype.

The question arises whether the use of the article within Greek is defined by the sort of attribute (participle vs. relative clause). This is, of course, a question concerning Greek pragmatics, and stands outside the comparison with Armenian, which makes use of a relative clause in both cases.

\section{Inferable definiteness}

If the definiteness of a NP is inferable from general (world-)knowledge, the article is used in Greek as well as in Armenian. Example (26) illustrates such inferable definiteness:

(26) kai iden duo ploiaria hestôta para tên limnên hoi de halieis ap' autôn apobantes eplunan ta diktua

ew etes erkows naws zi kayin ar covaki-n ; ew jknorsk'-n eleal ï noc'anē lowanayín z-gorcis-n

'And (he) saw two ships standing by the lake: but the fishermen were gone out of them, and were washing their nets.' (Lk 5:1-2)

Here the existence of ships automatically presupposes the existence of a crew, which then gets the definite article (hoi...halieis 'the fishermen'), even though it has not been mentioned before. The same goes for the nets. They, too, are an entirely new item, which nonetheless occur with definite article because their existence is inferable from the existence of the fishermen throwing them.

\section{"Associative definiteness"}

A special form of definiteness that is not easily positioned within the continuum used here, and which is actually rather rare within the New Testament corpus, can be tentatively called "associative definiteness". It is akin to inferable definiteness in that it is also based on common world-knowledge involving fixed associative images and scenes of a known or traceable situation. Cf. example (27):

(27) êdê de kai hê axinê pros tên rhizan tôn dendrôn keitai Bayc' ahawasik tapár ar armi-n cāroc' kay

'And now also the axe is laid unto the root of the trees.' (Lk 3:9)

\section{[5] CONCLUSIONS}

In this paper, the use of the definite article in semantic and pragmatic categories in the Greek and Classical Armenian New Testament translation has been compared. The evidence quoted in the paper can only serve as first approximation of some tendencies within these categories, and of course in all cases further investigation is necessary. It can be stated that Greek and Classical Armenian agree in their use of the definite article only in NPs determined by contrastive attributes (such as Greek 
allos, Arm. miws). In all other categories the systems of both languages differ. Generally, Armenian avoids the definite article with proper nouns and nouns with unique reference, while definite articles with proper names in Greek are common (with the exception of sacred or especially "respected" persons such as prophets). If the definite article is present in Greek, it is often motivated by pragmatic factors (e.g. re-topicalization, etc.). There is obviously no evidence in Armenian for the use of the definite article as a marker of generic reference, nor for the use in NPs determined by superlative, comparative or ordinal attributes.

Concerning Greenberg's "scales of definiteness", it can be argued that the definite article in Classical Armenian in its earliest attested stage is much less developed than in New Testament Greek. However, in order to decide whether there is any evidence for a development at all in the case of Armenian it would be necessary to look at the usage of the definite article in later stages of the language, e.g. in Middle Armenian texts, and to compare directly the New Testament translations of both varieties of modern Armenian spoken today. For a more precise description of the function of the definite article in Classical Armenian it is obvious that syntactic criteria must also be taken into consideration (e.g. the special environment within possessive phrases, etc.), as well as the presence or absence of the Classical Armenian nota accusativi $z^{-}$, which may condition the use of definite markers in important ways.

REFERENCES

Blass, F. \& A. Debrunner. 1979. Grammatik des neutestamentlichen Griechisch. Bearbeitet von F. Rehkopf. 15th ed. Göttingen: Vandenhoeck \& Ruprecht.

Dryer, M. S. 2005. Definite articles. In M. et al. Haspelmath (ed.), The World Atlas of Language Structures Online, Oxford: Oxford University Press. Available at http: //wals. info/feature/37, accessed 2010-08-30.

Greenberg, J. H. 1978. How does a language acquire gender markers? In J. H. Greenberg, Charles A. Ferguson \& E. A. Moravcsik (eds.), Universals of human language, vol. 1, 47-82. Stanford, Calif.: Stanford University Press.

Klein, J. S. 1996. On personal deixis in Classical Armenian. A study of the syntax and semantics of the n-, $s-$, and $d-$ demonstratives in manuscripts $E$ and $M$ of the Old Armenian Gospels. Dettelbach: Röll.

Löbner, S. 1985. Definites. Journal of Semantics 4. 279-326.

Lyons, C. 1999. Definiteness. Cambridge: Cambridge University Press.

Manolessou, I. \& G. Horrocks. 2007. The development of the definite article in Greek. In Studies in Greek linguistics. Proceedings of the annual meeting of the Department of Linguistics, School of Philology, Aristotele University of Thessaloniki, May 6-7, 2006, 224-236. 
Schulze, W. 2008. Deictic strategies in Udi. In M. E. Alekseev, T. A. Majsak, D. S. Ganenko \& Ju. A. Lander (eds.), Udinskij sbornik: Grammatika, leksika, istorija jazyka, 241-310. Moskva: Academia.

AUTHOR CONTACT INFORMATION

Angelika Müth

IFIKK, HF, University of Oslo

Box 1020 Blindern

$\mathrm{N}-0315$ Oslo

Norway

angelika.mueth@ifikk.uio.no 